\title{
Pyrrhonian Skepticism in Diogenes Laertius
}

Introduction, Text, Translation, Commentary and Interpretative Essays by Katja
Maria Vogt, Richard Bett, Lorenzo Corti, Tiziano Dorandi, Christiana M.M. Olfert,
Elisabeth Scharffenberger, David Sedley, James Warren. Ed. by Katja Maria Vogt

[Pyrrhonische Skepsis bei Diogenes Laertius.]

Veröffentlicht auf Englisch.

Noch vor wenigen Jahrzehnten wurde antike Skepsis in einem Atemzug mit moderner Außenweltskepsis als extrem verworfen, als ein Ansatz, den man bestenfalls widerlegen will. Inzwischen ist klar, dass antike Skeptiker ein Selbstverständnis als Untersuchende haben, das heutiger Forschung und Wissenschaft ähnelt. Sie untersuchen »weiter «: sie sind weder der Meinung, wahre Theorien gefunden zu haben, noch der Meinung, dass solche Theorien unauffindbar sind. Stattdessen verstehen sie die Suche nach Wissen als ein langfristiges Projekt und als eine Lebensform. Der vorliegende Band ist die erste griechisch-englische Studienausgabe eines der wichtigsten Texte zur pyrrhonischen Skepsis, Diogenes Laertius' Bericht in seinem Werk Leben und Meinungen berühmter Philosophen. Mit einer philosophischen Einleitung, Übersetzung, Kommentar und erläuternden Essays machen international führende Experten diesen zentralen Text der Erkenntnistheorie und Philosophiegeschichte zugänglich.

Katja Maria Vogt 1992 MA; 1997 Dr. phil.; taught at HU Berlin, then as Assistant Professor and Associate Professor at Columbia University, New York; since 2009 Professor of Philosophy, since 2011 Chair of the Classical Studies Graduate Program at Columbia University.

Richard Bett specializes in ancient Greek philosophy, with a particular focus on ethics and epistemology. He also has interests in modern ethics and epistemology, as well as a significant side-interest in Nietzsche.

2015. X, 202 Seiten. SAPERE XXV

ISBN 978-3-16-156430-7

DOI 10.1628/978-3-16-156430-7 eBook PDF

ISBN 978-3-16-153336-5

Leinen $69,00 €$ Lorenzo Corti is Lecturer in Ancient Philosophy at the University of Lorraine and member of the Archives Henri Poincaré at
Nancy, France. Corti specializes in ancient philosophy (ancient Greek scepticism, Hellenistic epistemologies, Aristotle's and
Plato's metaphysics) and philosophy of language.

Christiana M.M. Olfert is Assistant Professor of Philosophy at Tufts University. Olfert specializes in ancient philosophy and ethics. She is interested in questions such as: How does a concern for the truth feature in practical reasoning and in action? How do we learn about what is good? How does thinking about our practical goals and projects involve thinking about the future?

Elisabeth Scharffenberger teaches in the Department of Classics at Columbia University, New York. She works primarily on ancient Athenian tragedy and comedy, with a focus on Euripides and Aristophanes, and on ancient comic literature in prose and poetry. She is also interested in the history of ideas in antiquity and beyond, and in the reception of ancient texts, including biographical materials, from antiquity to the present day.

David Sedley is Emeritus Laurence Professor of Ancient Philosophy at the University of Cambridge, and a Fellow of Christ's College.

James Warren is a Reader in Ancient Philosophy at the University of Cambridge and Fellow and Director of Studies in Philosophy of Corpus Christi College.

Dorandi Tiziano is Director of Research in French National Center of Scientific Research (CNRS) UMR 8230-École Normale Supérieure. His intersts include Papyrology, Textual Criticism, Ancient Biography, and Ancient Philosophy.

Jetzt bestellen:

https://mohrsiebeck.com/buch/pyrrhonian-skepticism-in-diogenes-laertius-9783161564307?no_cache=1

order@mohrsiebeck.com

Telefon: +49 (0)7071-923-17

Telefax: +49(0)7071-51104 